\title{
Penegakan Hukum Dalam Tindak Pidana Pencemaran Lingkungan (Studi Kasus Putusan Nomor 55/Pid.B/LH/2016/PN.Pwk)
}

\author{
Indrianita Melissa Purnamasari \\ Magister Hukum Ekonomi, Fakultas Hukum, Universitas Indonesia \\ Depok, Indonesia \\ Email: indrianitamp16@gmail.com
}

\begin{abstract}
Abstrak. Artikel ini membahas mengenai pengaturan pertanggungjawaban pidana pengurus korporasi dalam kejahatan lingkungan serta bagaimana penegakan hukum lingungan hidup dalam tindak pidana pencemaran lingkungan Adapun dalam penelitian ini akan menggunakan sebuah kasus dengan nomor perkara 55/Pid.B/LH/2016/PN.Pwk sebagai acuan. Penelitian ini adalah penelitian normative yuridis dengan bentuk preskriptif, yang melakukan identifikasi pokok-pokok permasalahan yang hendak dibahas secara tuntas dengan norma hukum yang terdapat dalam peraturan perundang-undangan terkait. Hasil penelitian ini menemukan bahwa pengurus dalam kasus lingkungkan hidup dapat dimintakan pertanggungjawaban pidana karena sebagai pihak yang menjalankan perusahaan yang melakukan tindak pidana lingkungan hidup. Namun banyak dari penegakan kasus tindak pidana lingkungan hidup justru tidak meminta pertanggungjawaban korporasi sehingga memungkinkan korporasi yang sama melakukan tindak pidana lingkungan hidup.
\end{abstract}

Kata Kunci: Penegakan Hukum, Lingkungan Hidup, Pertanggungjawaban Pengurus

\begin{abstract}
This article discusses the regulation of criminal responsibility for corporate management in environmental crimes and how to enforce the environmental law in criminal acts of environmental pollution. In this study, we will use a case with case number 55 / Pid.B / LH / 2016 / PN.Pwk as a reference. This research is a juridical normative research in a prescriptive form, which identifies the main issues to be discussed thoroughly with the legal norms contained in the relevant laws and regulations. The results of this study found that management in environmental cases can be held responsible for the crime because they are the party who runs the company who has committed an environmental crime. However, many cases of environmental crime do not hold corporations accountable, allowing the same corporations to commit environmental crimes.
\end{abstract}

Keywords: Law Enforcement, Environment, Accountability of the Management

\section{PENDAHULUAN}

\section{Latar Belakang}

Dalam ilmu ekologi, manusia adalah satu kesatuan yang terpadu dengan lingkungannya. Kesatuan yang terpadu tersebut, mengartikan bahwa manusia dan lingkungan (alam) memiliki kedudukan yang sama dan mutlak saling membutuhkan. Kewajiban untuk menyelaraskan kedudukan antara manusia dan lingkungan juga tercermin dalam berbagai nilai yang hidup di masyarakat, berupa kebiasaan memitoskan alam dan konsep ajaran agama. Meskipun, pada dasarnya kedudukan antara manusia dan lingkungan adalah sama, tetapi manusia memiliki peran lebih karena memiliki daya akal. Menurut Cicero peran lebih yang dimiliki manusia berfungsi untuk menentukan tata susunan lingkungan, bukan untuk mengasai alam karena alam tidak dapat dikuasai.

Dalam rangka memperoleh taraf hidup yang lebih baik, manusia terus berupaya melakukan pembangunan. Pembangunan merupakan suatu hal yang dibutuhkan untuk mencapai kesejahteraan. Setiap pembangunan selalu terkait dengan pemanfaatan lingkungan, sehingga hal tersebut berpotensi terhadap merosotnya kualitas lingkungan. Merosotnya kualitas lingkungan dibarengi 
dengan menipisnya persediaan sumber daya alam, serta timbulnya berbagai permasalahan lingkungan. Menipisnya persedian sumber daya alam dan permasalahan lingkungan lainnya merupakan akibat dari ketidakseimbangan antara lingkungan hidup alami dan buatan karena ulah manusia yang berperan sebagai pelaku sekaligus korban.

Pemanfaatan lingkungan harus dilakukan dengan memperhatikan upaya perlindungan dan pengelolaan lingkungan hidup yang secara sederhana diartikan lingkungan harus dipertahankan sebagaimana keadaan awalnya. Tantangan untuk mempertahankan keadaan tersebut datang dari tuntutan pembangunan yang selalu berkaitan dengan pemanfaatan lingkungan. Hal ini menandakan bahwa lingkungan akan mengalami perubahan seiring dengan pelaksanaan pembangunan. Dalam proses perubahan tersebut, perlu dijaga agar lingkungan tetap mampu menunjang kehidupan yang normal, sesuai dengan daya dukung dan daya tampung lingkungan, bukan justru menimbulkan kerugian.

Namun, pada akhir ini muncul berbagai masalah akibat kerusakan lingkungan. Berbagai faktor menjadi penyebab terjadinya kerusakan lingkungan, misalnya pembukaan lahan dengan cara pembakaran yang mengakibatkan rusaknya ekosistem di wilayah tersebut. Hal ini tentunya mengakibatkan munculnya berbagai sengketa lingkungan. Saat ini, terdapat upaya penyelesaian sengketa lingkungan di luar pengadilan dan melalui pengadilan (administrasi, perdata, dan pidana).

Dalam pengaturan mengenai lingkungan hidup di Indonesia, pertanggungjawaban pidana pengurus korporasi atas perbuatan korporasi dalam hal kejahatan lingkungan justru dimungkinkan oleh peraturan perundang-undangan dan diterapkan oleh pengadilan. Berdasarkan Pasal 116 Undang-Undang Nomor 32 Tahun 2009 ("UUPPLH"), apabila tindak pidana lingkungan hidup dilakukan oleh, untuk, atau atas nama badan usaha, tuntutan dan sanksi pidana dijatuhkan kepada badan usaha, orang yang memberi perintah untuk melakukan atau memimpin kegiatan dalam tindak pidana tersebut, atau keduanya. Selanjutnya, Pasal 118 UUPPLH menetapkan bahwa:

Terhadap tindak pidana sebagaimana dimaksud dalam Pasal 116 ayat (1) huruf a, sanksi pidana dijatuhkan kepada badan usaha yang diwakili oleh pengurus yang berwenang mewakili di dalam dan di luar pengadilan sesuai dengan peraturan perundang-undangan selaku pelaku fungsional. Namun, dalam penjelasan Pasal 118 UUPPLH, terdapat penjelasan bahwa: "Tuntutan pidana dikenakan terhadap pemimpin badan usaha dan badan hukum karena tindak pidana badan usaha dan badan hukum adalah tindak pidana fungsional sehingga pidana dikenakan dan sanksi dijatuhkan kepada mereka yang memiliki kewenangan terhadap pelaku fisik dan menerima tindakan pelaku fisik tersebut."

Penjelasan ini menimbulkan interpretasi bahwa apabila badan usaha atau badan hukum dijatuhi hukuman, maka hukuman tersebut diberikan kepada pemimpin atau pengurus korporasi. sering ditemukan, di mana pengadilan menjatuhkan pidana kepada direktur korporasi dalam kapasitasnya sebagai individu hanya karena jabatan individu Interpretasi inilah yang dalam praktiknya tersebut sebagai direktur korporasi. Salah satu contohnya adalah putusan pengadilan negeri pekalongan nomor 55/Pid.B/LH/2016/PN.Pwk. tgl 31 Mei 2016.

Dalam penelitian ini penulis merujuk pada ketentuan dan putusan Indonesia mengenai pertanggungjawaban pidana pengurus korporasi serta penerapan hukum dalam kasus pencemaran lingkungan dengan studi kasus putusan nomor 55/Pid.B/LH/2016/PN.Pwk. tgl 31 Mei 2016.

\section{Rumusan Masalah}

1. Bagaimana Pengaturan pertanggungjawaban pidana pengurus korporasi dalam kejahatan lingkungan?

2. Bagaimana Penegakan Hukum Lingungan Hidup Dalam Tindak Pidana Pencemaran Lingkungan (Studi Kasus Putusan Nomor 55/Pid.B/LH/2016/PN.Pwk)? 


\section{METODE PENELITIAN}

Penelitian ini menggunakan metode preskriptif yuridis normatif yakni merupakan metode penelitian hukum kepustakaan atau penelitian hukum yang pelaksanaannya dilakukan dengan meneliti bahan pustaka yang ada. Dengan metode ini penulis akan melakukan penelitian dengan melakukan identifikasi pokok-pokok permasalahan yang hendak dibahas secara tuntas dengan norma hukum yang terdapat dalam peraturan perundang-undangan terkait.

Tipologi penelitian ini adalah penelitian preskriptif yakni penelitian yang bertujuan untuk mendapatkan saran-saran mengenai apa yang harus dilakukan untuk mengatasi masalah-masalah tertentu. Penulis memilih penelitian ini untuk mencari jawaban bagaimana pengaturan pertanggungjawaban pidana pengurus korporasi dalam tindak pidana lingkungan hidup.

Jenis data yang digunakan dalam penelitian ini adalah data sekunder yaitu data yang diperoleh langsung melalui penelusuran literatur hukum dan kepustakaan. Data sekunder mencakup dokumen-dokumen resmi, buku-buku, hasil- hasil penelitian yang berwujud laporan, buku harian dan seterusnya. Pada umumnya data sekunder dalam keadaan siap terbuat dan dapat dipergunakan dengan segera, baik bentuk maupun isi data sekunder telah dibentuk dan diisi oleh peneliti-peneliti terdahulu terhadap pengumpulan, pengelolaan, analisa maupun konstruksi data. Data sekunder tidak terbatas oleh waktu maupun tempat. Data sekunder terdiri atas:

1. Bahan hukum primer, meliputi peraturan perundang-undangan, putusan hakim, perjanjian, dan dokumen langsung yang bersifat asli.

2. Bahan Hukum Sekunder yakni meliputi buku dan artikel. Bahan hukum sekunder yang digunakan dalam penelitian ini hasil penelitian hukum yang terdapat dalam buku-buku, jurnal-jurnal, pendapat para ahli, hasil karya ilmiah, dan komentarkomentar dari kalangan hukum. Bahan hukum sekunder yang digunakan berisi mengenai isu-isu yang relevan dengan topik penelitian.

3. Bahan Hukum Tersier yakni meliputi kamus, peta, buku telepon, bibliografi, indeks, dan lain-lain. Bahan hukum tersier yang digunakan dalam skripsi ini, yaitu kamus hukum dan Kamus Besar Bahasa Indonesia (KBBI).

Dalam penelitian ini pengumpulan data sekunder dilakukan melalui studi kepustakaan. Pengumpulan data sekunder yang dilakukan melalui studi kepustakaan dengan menggunakan bahan-bahan dari buku, artikel yang dapat diakses secara online, dan data lainnya yang dapat mendukung penelitian ini. Studi kepustakaan dilakukan di beberapa tempat seperti perpustakaan Fakultas Hukum Universitas Indonesia.

Data yang telah diperoleh selanjutnya akan dianalisis secara kualitatif, artinya data yang telah didapat disusun secara sistematis dalam bentuk uraian atau penjelasan untuk menggambarkan hasil penelitian sehingga mudah dipahami agar dapat diinformasikan kepada orang lain. Menganalisa data secara kualitatif yaitu dengan pemahaman persepsi dan pemikiran sistematis Penulis terhadap data-data yang ada, dengan tujuan untuk menemukan jawaban terhadap permasalahan dalam penelitian ini. Analisis data kualitatif ini lebih mengutamakan aspek kualitas dari data yang tidak dapat dirumuskan dengan perhitungan matematis atau statistik semata.

\section{PEMBAHASAN}

\section{Pengaturan Pertanggungjawaban Pidana Pengurus Korporasi Dalam Kejahatan Lingkungan Hidup}

a. Undang-Undang No. 32 Tahun 2009 tentang Perlindungan dan Pengelolaan Lingkungan Hidup

Pembuatan Undang-Undang No. 32 Tahun 2009 tentang Perlindungan dan Pengelolaan Lingkungan Hidup ("UUPPLH") didasari dengan adanya kebutuhan akan suatu sistem yang terpadu terkait perlindungan dan pengelolaan lingkungan hidup yang harus dilaksanakan secara taat asas. Selain itu, pembuatan UUPPLH juga didasari atas 
kesadaran menurunnya kualitas lingkungan hidup yang mengancam kelangsungan perikehidupan manusia sehingga dibutuhkan adanya perlindungan dan pengelolaan lingkungan hidup oleh semua pemangku kepentingan. UUPPLH mengatur secara umum mengenai perlindungan dan pengelolaan lingkungan hidup disamping undang-undang lainnya atau sectoral.

Terdapat perbedaan mengenai ketentuan pidana dalam UUPPLH dengan undang-undang yang mengatur mengenai lingkungan hidup sebelumnya yaitu Undang-Undang No. 23 Tahun 1997 tentang Pengelolaan Lingkungan Hidup. Perbedaan tersebut di antaranya adalah adanya ancaman hukuman minimum di samping maksimum, perluasan alat bukti, pemidanaan bagi pelanggaran baku mutu, keterpaduan penegakan hukum pidana, serta pengaturan tindak pidana korporasi. Pengaturan tindak pidana korporasi dalam UUPPLH terdapat dalam Pasal 116 hingga Pasal 120. Bagian ini akan membahas bagian-bagian yang relevan dengan pertanggungjawaban pidana pengurus korporasi. Pasal 116 mengatur bahwa:

1. Apabila tindak pidana lingkungan hidup dilakukan oleh, untuk, atau atas nama badan usaha, tuntutan pidana dan sanksi pidana dijatuhkan kepada:

a) badan usaha; dan/atau

b) orang yang memberi perintah untuk melakukan tindak pidana tersebut atau orang yang bertindak sebagai pemimpin kegiatan dalam tindak pidana tersebut.

2. Apabila tindak pidana lingkungan hidup sebagaimana dimaksud pada ayat (1) dilakukan oleh orang, yang berdasarkan hubungan kerja atau berdasarkan hubungan lain yang bertindak dalam lingkup kerja badan usaha, sanksi pidana dijatuhkan terhadap pemberi perintah atau pemimpin dalam

\author{
tindak pidana tersebut tanpa \\ memperhatikan tindak pidana \\ tersebut dilakukan secara sendiri \\ atau bersama-sama.
}

Pasal 118 UUPPLH mengatur bahwa:

"Terhadap tindak pidana sebagaimana dimaksud dalam Pasal 116 ayat (1) huruf a, sanksi pidana dijatuhkan kepada badan usaha yang diwakili oleh pengurus yang berwenang mewakili di dalam dan di luar pengadilan sesuai dengan peraturan perundangundangan selaku pelaku fungsional."

Penjelasan Pasal 118 UUPPH menjelaskan bahwa Yang dimaksud dengan pelaku fungsional dalam Pasal ini adalah badan usaha dan badan hukum. Selain itu tuntutan pidana dikenakan terhadap pemimpin badan usaha dan badan hukum karena tindak pidana badan usaha dan badan hukum adalah tindak pidana fungsional sehingga pidana dikenakan dan sanksi dijatuhkan kepada mereka yang memiliki kewenangan terhadap pelaku fisik dan menerima tindakan pelaku fisik tersebut. Yang dimaksud dengan menerima tindakan dalam Pasal ini termasuk menyetujui, membiarkan, atau tidak cukup melakukan pengawasan terhadap tindakan pelaku fisik, dan/atau memiliki kebijakan yang memungkinkan terjadinya tindak pidana tersebut.

Ketentuan-ketentuan di atas menimbulkan kerancuan dalam menetapkan sistem pertanggungjawaban pidana pengurus korporasi. Menurut Wibisana, apabila Pasal 116 ayat (1), Pasal 118 dan penjelasan Pasal 118 dibaca secara bersamaan, maka terdapat interpretasi yang berbeda mengenai kepada siapa, selain korporasi, tuntutan dan sanksi pidana dapat dijatuhkan apabila tindak pidana dilakukan oleh korporasi. Apabila hanya berdasarkan Pasal 116 ayat (1), maka dapat dipahami bahwa apabila tindak pidana dilakukan oleh korporasi, maka tuntutan dan sanksi pidana juga dapat dijatuhkan kepada orang yang memberi perintah atau bertindak sebagai pemimpin dalam tindak pidana tersebut. Oleh karena itu, Pasal 116 ayat (1) tidak menggunakan teori individual vicarious liability karena berdasarkan kata-kata dalam pasal ini, yang bertanggung jawab bukanlah 
pemimpin korporasi seperti direktur atau manajer, tetapi pemimpin atau pemberi perintah dalam tindak pidana, terlepas dari jabatan orang tersebut. Apabila ia merupakan pemimpin atau pemberi perintah dalam tindak pidana, maka ia juga merupakan pelaku sehingga pertanggungjawabannya bukan turunan dari tindak pidana korporasi.

Wibisana menemukan kemungkinan diterapkannya individual vicarious liability apabila Pasal 116 dan Pasal 118 turut dibaca dengan Penjelasan Pasal 118. Dalam penjelasan pasal tersebut, terdapat frasa "tuntutan pidana dikenakan terhadap pemimpin badan usaha dan badan hukum". Frasa ini membuat dimungkinkannya diterapkan individual vicarious liabiltiy, karena sanksi dapat ditujukan kepada pemimpin korporasi apabila tuntutan dijatuhkan kepada korporasi. Berbeda dengan apa yang dimaksud dalam Pasal 118, dalam penjelasannya, pemimpin bukan hanya bertindak sebagai wakil korporasi tetapi pemimpin jugalah yang menerima sanksi pidana.

Selain itu, ketentuan pidana dalam UUPPLH membuat korporasi dapat dibebankan pidana penjara. Hal ini dapat dilihat dari rumusan Pasal 119 yang menyatakan selain pidana sebagaimana dimaksud dalam Undang-Undang ini, terhadap badan usaha dapat dikenakan pidana tambahan atau tindakan tata tertib berupa..." Pasal ini mengatur mengenai pidana tambahan atau tindakan tata tertib yang dapat dibebankan selain "pidana sebagaimana dimaksud dalam Undang- Undang ini" yaitu pidana pokok. Dengan konstruksi ini, maka pidana pokok harus diberikan. Pidana pokok yang diatur dalam Pasal 98 hingga Pasal 115 UUPPLH adalah penjara dan denda. Sehingga, korporasi dimungkinkan untuk dipenjara berdasarkan UUPPLH.

Pasal 116 ayat 1 UUPPLH membebankan pidana kepada "orang yang memberi perintah" atau "orang yang bertindak sebagai pemimpin". Menurut Sjahdeini, redaksi dari Pasal 116 ayat (1) UUPPLH merupakan adopsi dari pemikiran yang terdapat dalam Pasal 51 KUHP Belanda yang mengatur:

1. tindak pidana dapat dilakukan baik oleh perorangan maupun oleh badan hukum. Jika suatu tindak pidana dilakukan oleh badan hukum.

2. Penuntutan pidana dapat dijalankan dan sanksi pidana maupun tindakan yang disediakan dalam perundangundangan -sepanjang berkenaan dengan badan hukum- dapat dijatuhkan. Dalam hal ini, pengenaan sanksi dapat dilakukan terhadap:

a. badan hukum sendiri, atau

b. mereka yang secara faktual memberikan perintah untuk melakukan tindak pidana yang dimaksud, termasuk mereka yang secara faktual memimpin pelaksanaan tindak pidana yang dimaksud, atau

c. badan hukum atau mereka yang disebut dalam butir b bersamasama secara tanggung renteng.

3. Berkenaan dengan penerapan butirbutir sebelumnya, yang disamakan dengan badan hukum: persekutuan bukan badan hukum, maatschap (persekutuan perdata), rederij (perusahaan perkapalan), dan doelvermogen (harta kekayaan yang dipisahkan demi pencapaian tujuan tertentu; social fund atau yayasan)."

Hoge Raad (Mahkamah Agung Belanda) melalui penetapan 19 November 1987 menetapkan bahwa apa yang dimaksud dengan secara factual memimpin dilakukannya suatu tindak pidana korporasi adalah bila ia mengetahui terjadinya tindak pidana tersebut. Selain itu, dalam keputusan Majelis Hakim Hoge Raad tanggal 16 Desember 1986, Nj 1987, 321, Hoge Raad menginterpretasikan perbuatan memimpin tindak pidana sebagai tindakan di mana:

...pejabat yang bersangkutan tidak mengambil langkah-langkah apa pun untuk mencegah dilakukannya perbuatan terlarang oleh para pegawainya, sekalipun ia berwenang untuk melakukan hal itu dan secara 
rasional dapat melakukan pencegahan yang dimaksud, dan bahkan secara sadar ia membiarkan perbuatan terlarang itu terlaksana sekalipun ada kesempatan untuk melakukan pencegahan terlaksananya perbuatan terlarang itu."

Di indonesia seperti yang disampaikan oleh Wibisana bahwa pengadilan masih menginterpretasikan bahwa Pasal 116 ayat (1) sebagai ketentuan dengan teori individual vicarious liability. Terlebih lagi, dalam penjelasan Pasal 118 terdapat frasa "tuntutan pidana dikenakan terhadap pemimpin badan usaha dan badan hukum" yang mendukung Pasal 116 ayat (1) untuk diinterpretasikan sebagai individual vicarious liability. Interpretasi ini berbeda dengan apa yang dimaksud dengan memberi perintah dan memimpin menurut Hoge Raad dan Remmelink. Apabila Pasal 116 ayat (1), Pasal 118, dan Penjelasan Pasal 118 bertujuan untuk memidana pemberi perintah atau pemimpin kegiatan pidana, maka harus dinyatakan hal tersebut lebih jelas dan meniadakan kata-kata dalam Penjelasan Pasal 118.

Ketentuan individual vicarious liability juga dapat ditemukan dalam POEO Act Australia. Namun, terdapat perbedaan antara section 169 POEO Act dengan ketentuan mengenai pertanggungjawaban pengurus korporasi dalam UUPPLH apabila diinterpretasikan sebagai individual vicarious liability. Pertama, ketentuan individual vicarious liability atau special executive liability dalam POEO Act hanya berlaku terhadap tindak pidana tertentu yang secara eksplisit ditentukan dalam section 169. Kedua, pengurus akan bertanggung jawab atas kesalahan korporasi kecuali apabila ia dapat membuktikan bahwa ia tidak berada dalam posisi "to influence the conduct of the corporation on relation to its contravention of the provision," atau apabila ia berada dalam posisi tersebut, ia telah "used all due diligence to prevent the contravention by the corporation." Pembelaan seperti ini tidak terdapat dalam UUPPLH. Oleh karena itu, pengurus korporasi dapat dipidana terlepas dari apakah ia dapat mencegah atau sudah melakukan segala cara untuk mencegah dilakukannya tindak pidana.

Ketentuan mengenai apa yang dimaksud dengan tindak korporasi tidak diatur dalam UUPPLH. Selain itu, UUPPLH tidak memiliki ketentuan yang jelas mengenai kapan pengurus korporasi dapat dipidana. Hal ini menimbulkan kesimpangsiuran antara pertanggungjawaban pidana korporasi dan pertanggungjawaban pidana pengurus korporasi.

b. Undang-Undang No. 23 Tahun 1997 tentang Pengelolaan Lingkungan Hidup Sebelum UUPPLH berlaku, ketentuan mengenai pengelolaan lingkungan hidup diatur dalam UndangUndang No. 23 Tahun 1997 tentang Pengelolaan Lingkungan Hidup ("UUPLH"). Ketentuan pidana UUPLH diatur dalam Pasal 41 hingga Pasal 48. UUPLH sudah mengenal pertanggungjawaban pidana korporasi, seperti yang dapat dilihat dalam Pasal 46. Pasal 46 ayat (1) mengatur bahwa: Jika tindak pidana sebagaimana dimaksud dalam Bab ini dilakukan oleh atau atas nama badan hukum, perseroan, perserikatan, yayasan atau organisasi lain, tuntutan pidana dilakukan dan sanksi pidana serta tindakan tata tertib sebagaimana dimaksud dalam Pasal 47 dijatuhkan baik terhadap badan hukum, perseroan, perserikatan, yayasan atau organisasi lain tersebut maupun terhadap mereka yang memberi perintah untuk melakukan tindak pidana tersebut atau yang bertindak sebagai pemimpin dalam perbuatan itu atau terhadap keduaduanya.

Ketentuan ini serupa dengan Pasal 116 UUPPLH. Perbedaan terdapat pada terminologi subjek dalam pasal tersebut. Dalam Pasal 46 UUPLH, subjeknya adalah badan hukum, perseroan, perserikatan, yayasan atau organisasi lain, sedangkan dalam Pasal 116 UUPPLH subjeknya adalah badan usaha. Terminologi badan usaha digunakan dalam Pasal 116 salah satunya demi 
keseragaman dengan terminologi yang digunakan dengan undang-undang lain seperti Undang-Undang No. 30 Tahun 2009 tentang Ketenagalistrikan dan Undang-Undang No. 4 Tahun 2009 tentang Pertambangan Mineral dan Batubara. Selain itu, perubahan terminologi dalam Pasal 116 UUPPLH juga bertujuan untuk merapikan terminologi dalam Pasal 46 UUPLH, karena perseroan dan yayasan juga merupakan badan hukum.

Dalam pasal 116 UUPLH pada intinya memiliki kesamaan dalam hal menentukan pihak yang dapat dimintakan pertanggungjawaban pidana. Apabila "badan hukum, perseroan, perserikatan, yayasan atau organisasi lain" melakukan tindak pidana, maka yang dapat dimintakan pertanggungjawaban atas tindak pidana tersebut dapat berupa organisasi yang melakukan tindak pidana, atau orang yang "memberi perintah untuk melakukan tindak pidana tersebut atau yang bertindak sebagai pemimpin dalam perbuatan itu", atau keduanya. Terminologi ini serupa dengan UUPPLH. Seperti yang telah dibahas sebelumnya, apabila yang dapat dipidana adalah orang yang memberi perintah atau memimpin, maka ketentuan ini tidak menggunakan teori individual vicarious liability. Orang yang memberi perintah atau memimpin juga terlibat dalam tindak pidana, sehingga terdapat kesalahan yang dapat dimintakan pertanggungjawaban. Ketentuan ini sudah cukup jelas tidak membebankan pertanggungjawaban pidana kepada pemimpin korporasi hanya karena posisinya sebagai pemimpin dalam korporasi. Tidak pula terdapat penjelasan yang membuat ketentuan ini menjadi rancu seperti Penjelasan Pasal 118 UUPPLH.

2. Penegakan Hukum Lingungan Hidup Dalam Tindak Pidana Pencemaran Lingkungan (Studi Kasus Putusan Nomor 55/Pid.B/LH/2016/PN.Pwk.)

a. Terdakwa. Terdakwa bernama Andrian Sadikin alias Ayen yang merupakan direktur sekaligus pemilik dari PT Assa Paper yang bergerak dibidang di bidang produksi kertas medium sejak tahun 2012.

b. Dakwaan Jaksa Penuntut Umum. Jenis dakwaan jaksa yakni alternative yakni:

1) dakwaan Pertama

a) Bahwa terdakwa selaku Direktur Utama PT Assa Paper merupakan pemimpin kegiatan proses produksi di PT Assa Paper dan terdakwa membiarkan limbah yang dihasilkan PT Assa Paper dibuang dan ditimbun ke media tanah tanpa proses pengelolaan terlebih dahulu serta tidak melakukan tindakan yang cukup untuk mencegah hal tersebut terjadi, sehingga menurut ketentuan Pasal 116 ayat (1) huruf b UUPPLH terhadap terdakwa dapat dimintakan pertanggungjawaban pidana.

b) Perbuatan terdakwa sebagaimana diatur dan diancam pidana berdasarkan Pasal 103 jo. Pasal 116 (1) huruf b UUPPLH.

Pasal 103

"Setiap orang yang menghasilkan limbah B3 dan tidak melakukan pengelolaan sebagaimana dimaksud dalam Pasal 59, dipidana dengan pidana penjara paling singkat 1 (satu) tahun dan paling lama 3 (tiga) tahun dan denda paling sedikit Rp1.000.000.000,00 (satu miliar rupiah) dan paling banyak Rp3.000.000.000,00 (tiga miliar rupiah). “

Pasal 59

1. Setiap orang yang menghasilkan limbah B3 wajib melakukan pengelolaan limbah B3 yang dihasilkannya.

2. Dalam hal B3 sebagaimana dimaksud dalam Pasal 58 ayat (1) telah kedaluwarsa, pengelolaannya mengikuti ketentuan pengelolaan limbah B3.

3. Dalam hal setiap orang tidak mampu melakukan sendiri pengelolaan limbah B3, pengelolaannya diserahkan kepada pihak lain.

4. Pengelolaan limbah B3 wajib mendapat izin dari Menteri, gubernur, atau bupati/walikota sesuai dengan kewenangannya. 
5. Menteri, gubernur, atau bupati/walikota wajib mencantumkan persyaratan lingkungan hidup yang harus dipenuhi dan kewajiban yang harus dipatuhi pengelola limbah B3 dalam izin.

6. Keputusan pemberian izin wajib diumumkan.

7. Ketentuan lebih lanjut mengenai pengelolaan limbah B3 diatur dalam Peraturan Pemerintah.

Pasal 116 ayat (1): "Apabila tindak pidana lingkungan hidup dilakukan oleh, untuk, atau atas nama badan usaha, tuntutan pidana dan sanksi pidana dijatuhkan kepada:

a) badan usaha; dan/atau

b) orang yang memberi perintah untuk melakukan tindak pidana tersebut atau orang yang bertindak sebagai pemimpin kegiatan dalam tindak pidana tersebut."

\section{2) Dakwaan kedua}

a) Bahwa terdakwa selaku Direktur Utama PT Assa Paper merupakan pemimpin kegiatan proses produksi di PT Assa Paper dan terdakwa membiarkan limbah yang dihasilkan PT Assa Paper dibuang dan ditimbun ke media tanah tanpa adanya izin dari pihak yang berwenang serta tidak melakukan tindakan yang cukup untuk mencegah hal tersebut terjadi, sehingga menurut ketentuan Pasal 116 ayat (1) huruf b UUPPLH terhadap terdakwa dapat dimintakan pertanggungjawaban pidana.

b) Perbuatan terdakwa sebagaimana diatur dan diancam pidana berdasarkan Pasal 104 jo. Pasal 116 ayat (1) huruf $b$ UUPPLH.

- Pasal 104: "Setiap orang yang melakukan dumping limbah dan/atau bahan ke media lingkungan hidup tanpa izin sebagaimana dimaksud dalam Pasal 60, dipidana dengan pidana penjara paling lama 3 (tiga) tahun dan denda paling banyak Rp3.000.000.000,00 (tiga miliar rupiah)."
- Pasal 116 ayat (1): “Apabila tindak pidana lingkungan hidup dilakukan oleh, untuk, atau atas nama badan usaha, tuntutan pidana dan sanksi pidana dijatuhkan kepada:

a) badan usaha; dan/atau

b) orang yang memberi perintah untuk melakukan tindak pidana tersebut atau orang yang bertindak sebagai pemimpin kegiatan dalam tindak pidana tersebut."

- Pasal 60: "Setiap orang dilarang melakukan dumping limbah dan/atau bahan ke media lingkungan hidup tanpa izin."

\section{c. Tuntutan Jaksa Penuntut Umum}

1. Menyatakan terdakwa ANDRIAN SADIKIN alias AYEN terbukti bersalah melakukan tindak pidana "melakukan dumping limbah dan/ atau bahan ke media lingkungan hidup tanpa izin" sebagaimana dalam dakwaan melanggar Pasal 104 jo. Pasal 116 ayat (1) huruf b UndangUndang No. 32 Tahun 2009 tentang Perlindungan dan Pengelolaan Lingkungan Hidup.

2. Menjatuhkan pidana terhadap terdakwa dengan pidana penjara selama 1 (satu) tahun dan 3 (tiga) bulan dengan perintah terdakwa segera ditahan Dan Denda sebesar Rp. 100.000.000,- (seratus juta rupiah) Subsidair 3 (tiga) bulan penjara.

3. menyatakan barang bukti berupa (dalam putusan)

4. Membebankan kepada terdakwa untuk membayar biaya perkara sebesar Rp.5.000,- (lima ribu) rupiah.

\section{d. Kronologis Kasus}

1. Adrian Sadikin adalah direktur utama PT Assa Paper yang jug amerupakan pemilik dari PT Assa Papper. pabrik milik PT Assa Paper yang berlokasi di Jl. Cibatu Raya Km. 9, Kp. Ciparung Sari RT 09 RW 02, Desa Ciparung Sari, Kec, Cibatu, Kab. Purwakarta. 
2. Tindakan yang didakwakan oleh Adrian Sadikin yakni sekitar tahun 2014 yakni melakukan "untuk, atau atas nama badan usaha PT Assa Paper, menghasilkan limbah B3 dan tidak melakukan pengelolaan sebagaimana dimaksud Pasal 59 UUPPLH".

3. PT Assa Paper merupakan perusahaan yang bergerak di bidang produksi kertas medium yang mulai beroperasi pada tahun 2014. Dalam melakukan produksi kertas medium, dibutuhkan bahan baku berupa kertas karton bekas, dan air dengan proses produksi yaitu kertas karton bekas dimasukkan kedalam sebuah mesin yang bernama stock fret untuk mencampur kertas dengan air, kemudian dilakukan pemilahan terhadap bahan pasir, plastic dan besi sehingga dihasilkan suatu kertas murni, setelah itu kertas murni akan dicurahkan kedalam sebuah mesin yang disebut wiryer untuk menjadi kertas basah dan terakhir akan dimasukkan kedalam mesin pengering untuk menjadi kertas medium ukuran 70 sd 125.

4. Dalam produksi kertas medium tersebut PT Assa Paper menggunakan beberapa bahan kimia yaitu BAC (Basic Aluminium Klorit) dan Polimer dan batu bara sebagai bahan bakar penggerak mesin, dimana dari proses produksi tersebut menghasilkan limbah cair berupa air limbah, dan limbah padat berupa sludge IPAL yang merupakan konsentrat kontaminan air limbah berbentuk padatan, dan fly ash/bottom ash yang merupakan limbah proses pembakaran batubara.

5. Terhadap limbah cair dan padat tersebut tidak dilakukan pengelolaan terlebih dahulu, melainkan langsung dibuang dan ditimbun ke media tanah di kawasan pabrik PT Assa Paper, sehingga terjadi percampuran air limbah dan fly ash/bottom ash di media tanah.
6. berdasarkan PP No. 101 Tahun 2014 tentang Pengelolaan Limbah B3 (Bahan Berbahaya dan Beracun) Lampiran 1 Tabel 3 Kode Industri 51, Kode B351-2 dan Tabel 4 Kode Limbah B409 - B410 maka fly ash/bottom ash dikategorikan sebagai limbah B3 yang menurut ketentuan Pasal 59 UUPPLH harus dilakukan pengelolaan, baik dalam hal pengurangan, penyimpanan, pengumpulan, pengangkutan, pemanfaatan, pengolahan dan/atau penimbunannya.

7. Selaint itu adnaya surat Teguran dan Himbauan dari Badan Lingkungan Hidup Kabupaten Purwakarta yang ditujukan kepada PT Assa Paper yaitu himbauan tentang pengelolaan limbah yang dihasilkan pabrik PT Assa Paper baik limbah cair maupun limbah padatnya, himbauan pengelolaan Limbah B3 telah dilakukan terhadap PT Assa Paper sejak tahun 2012 sampai tahun 2014 .

\section{e. Putusan Majelis Hakim}

1. Menyatakan terdakwa Andrian Sadikin Alias Ayen telah terbukti secara sah dan meyakinkan bersalah melakukan tindak pidana "melakukan dumping limbah dan bahan B3 (Bahan Berbahaya dan Beracun) ke media lingkungan hidup tanpa izin".

2. Menjatuhkan pidana terhadap Terdakwa tersebut diatas dengan Pidana Penjara selama: 10 (sepuluh) Bulan, dan Denda sebesar Rp. 100.000.000,- (seratus juta rupiah), dengan ketentuan apabila denda tersebut tidak dibayar maka harus diganti dengan pidana penjara selama: 2 (dua) bulan.

3. Menyatakan barang bukti berupa (terlampir dalam putusan).

4. Membebankan kepada Terdakwa untuk membayar biaya perkara sebesar Rp.5.000,- (lima ribu) rupiah.

\section{f. Analisa Unsur Pasal 104 UUPPLH}

\section{Unsur Setiap Orang :}


a) Setiap orang disini maksudnya adalah siapa saja yaitu manusia sebagai subjek hukum yang dapat mempertanggungjawabkan

perbuatan yang telah dilakukanya dan didalam diri manusia tersebut tidak ditemukan alasan penghapus pidana baik berupa alasan yang dapat menghilangkan sifat melawan hukum atas adanya sesuatu perbuatan yang telah dilakukannya ataupun alasan peniadaan kesalahan.

b) Setiap Orang" dalam Pasal 1 angka 32 Undang-Undang Nomor 32 Tahun 2009 tentang Perlindungan dan Pengelolaan Lingkungan Hidup dimaksud adalah orang perorangan atau badan usaha, baik yang berbadan hukum maupun yang tidak berbadan hukum.

c) Andrian Sadikin Alias Ayen selaku pimpinan dan direktur PT Assa Paper, identitas mana terdakwa sebagaimana dalam surat dakwaan Jaksa Penuntut Umum tersebut baik saksi- saksi maupun Terdakwa membenarkan identitas yang dibacakan dimuka persidangan sehingga tidak terjadi error in persona dalam perkara ini.

d) Selain itu dipersidangan telah menunjukkan kecakapan dan kemampuannya dalam arti baik fisik dan psikisnya sehat dan memadai (sehat jasmani maupun rohaninya) serta pada terdakwa tidak ditemukan adanya halangan yang biasa dijadikan alasan pembenar dan penghapus pidana sehingga terdakwa dapat mempertanggung jawabkan atas perbuatannya secara hukum.

\section{Unsur melakukan Dumping limbah} dan atau bahan ke media lingkungan hidup tanpa izin
a) Pengerian
Dumping

(Pembuangan) adalah kegiatan membuang, menempatkan, dan / atau memasukkan limbah dan/atau bahan dalam jumlah, konsentrasi, waktu dan lokasi tertentu dengan persyaratan tertentu ke media lingkungan hidup tertentu. Limbah Bahan Berbahaya dan Beracun / Limbah B3 adalah sisa suatu usaha dan /atau kegiatan yang mengandung B3 (Pasal 1 butir 21). pengelolaan Limbah $\mathbf{B 3}$ adalah kegiatan yang meliputi pengurangan, penyimpanan, pengumpulan, pengangkutan, pemanfaatan, pengolahan dan / atau penimbunan. Kriteria Pencemaran Lingkungan Hidup tergantung dari baku mutu yang menjadi ukuran setelah melalui penelitian bahwa limbah yang berada di bawah standar baku mutu tetap berdampak tidak baik dan berbahaya bagi lingkungan.

b) bahwa dalam proses produksinya PT Assa Paper mengunakan bahan bakar berupa batu bara untuk menghidupkan mesin boillernya, dan sisa pembakaran batu bara menghasilkan limbah batubara berupa fly ash dan bottom ash, yang didalamnya ada kimia yang berbahaya bagi kehidupan makhluk hidup baik manusia, hewan maupun tumbuhan juga kerusakan lingkungan hidup apabila tercemar.

c) Berdasarkan hasil uji dari lab yang dilakukan terhadap sampel limbah yang diambil dari lokasi penimbunan dan pembuangan limbah batu bara yang diambil Petugas dari BLH Kabupaten Purwakarta dan keterangan AHLI dalam perkara pidana ini telah membuktikan benar dalam limbah batu bara fly ash dan bottom ash mengandung B3 (bahan berbahaya dan beracun), sehingga tidak diperkenankan kepada 
siapapun juga untuk dibuang secara langsung ke media lingkungan manapun.

d) selanjutnya dari pemeriksaan sidang setempat (PS) PT Assa Paper yang pemiliknya / direktur utamanya adalah terdakwa ANDRIAN als AYEN benar telah menempatkan, membuang dan menimbun limbah batu bara fly ash dan bottom ash tidak pada tempatnya yang seharusnya ditempatkan dan dibuang di TPS (tempat pembuangan sementara) yang syarat dan ketentuan standar dan kriterianya sebagaimana ditentukan oleh Kementerian Lingkungan Hidup, contohnya diharuskan atap dan alasnya kedap udara dan kedap air, kemudian dalam waktu 90 (sembilan puluh hari) limbah batubara tersebut harus sudah diangkut dari TPS oleh pihak ketiga sebagai transforter untuk diberikan kepada pemanfaat limbah yang mempunyai izin dari pihak yang berwenang.

e) saksi-saksi yang telah didengar keterangannya di muka persidangan bahwa benar PT Assa Paper telah membuang langsung limbah berbahaya berupa limbah batubara fly ash/bottom ash ke media tanah di sekitar areal Perusahaan dan telah membuang limbah cair yang seharusnya diproses melalui bak IPAL untuk diproses, kemudian limbah dialirkan melalui pipa-pipa yang seharusnya tanpa adanya ceceran dan tetesan air limbah langsung ke media tanah namun ternyata IPAL yang ada tidak difungsikan sebagaimana peruntukannya.

f) limbah batubara fly ash dan bottom ash yang merupakan limbah B3 dan berdasarkan hasil Lab telah membuktikan benar limbah batu bara yang dibuang langsung ke media tanah yang ditimbun dan diurug dengan tanah merah yang dijadikan sampel pemeriksaan dalam perkara terdakwa ini jelas ada mengandung logam-logam berat dan berdasarkan Peraturan Pemerintah No.18 Tahun 1999 Jo Peraturan Pemerintah No.85 Tahun 1999 tentang Pengolahan Limbah B-3 menyebutkan limbah padat abu batu bara bottom ash adalah mengandung logam berat digolongkan sebagai limbah B-3 (bahan berbahaya dan beracun) dan karakter tonsik.

g) Selain itu terhadap limbah cair dan limbah padat yang dikeluarkan oleh PT ASSA PAPER dalam produksi tersebut ternyata tidak dilakukan proses pengelolaan dan pengolahan limbah terlebih dahulu sebagaimana mestinya yang ditentukan oleh Undang-Undang Pelindungan dan Pengelolaan Lingkungan Hidup, melainkan ternyata limbah batubara berupa fly ash dan bottom ash langsung dibuang oleh PT Assa Paper ke media tanah angsung yang diatasnya kemudian ditimbun dengan tanah merah, limbah batubara berupa fly ash dan bottom ash tersebut dibuang dan ditempatkan di areal sebidang tanah tanah yang berada di dalam kawasan pabrik PT ASSA PAPER.

h) Tempat pembuangan dan penimbunan limbah batu bara berupa fly ash dan bottom ash tersebut letaknya tidak begitu jauh dari Sungai Cisadae sehingga telah terjadi percampuran air limbah dan fly ash/bottom ash di tempat media tanah tempat pembuangan dan penimbunan tersebut berada. Hal ini diperkuat 
berdasarkan hasil sidang pemeriksaan setempat (PS).

i) Berdasarkan pertimbanganpertimbangan tersebut di atas maka Unsur kedua "melakukan dumping limbah dan / atau bahan ke media lingkungan hidup tanpa izin" telah terpenuhi dan terbukti.

3. Unsur "Apabila tindak pidana lingkungan hidup dilakukan oleh, untuk, atau atas nama badan usaha, tuntutan pidana dan sanksi pidana dijatuhkan kepada orang yang memberi perintah untuk melakukan tindak pidana tersebut atau orang yang bertindak sebagai pemimpin kegiatan dalam tindak pidana tersebut"

a) berdasarkan keterangan saksi Antonius Rasep yang mengatakan penimbunan yang dilakukan saksi dengan tanah merah adalah benar di atas buangan limbah batu bara berupa fly ash dan bottom ash, dan yang memerintahkan saksi melakukannya adalah sdr Miming (orang kepercayaan terdakwa) dan kemudian saksi menerangkan bahwa terdakwa selaku direktur utama sekaligus pemilik perusahaan selalu rutin datang tiap minggu ke pabrik untuk mengawasi kerja karwyawannya.

b) saksi lain juga menerangkan bahwa yang melakukan penimbunan terhadap limbah batu bara berupa bottom ash dan fly ash sebanyak 60 ton dengan urugan tanah merah adalah sdr Anton selaku Kabag Umum ertanggungjawab kepada sdr. Hong Cai Ming selaku General Manager di PT Assa Paper yang menyapaikan langsung ke terdawka.

c) Tindakan Andrian Sadikin berdaarkan fakta terbukti tidak mau bertindak dan tidak mengawasi karyawannya /anak buahnya serta membiarkan mereka menempatkan, menimbun limbah baubara ke media tanah langsung/ membuang limbah batu bara tidak pada tempatnya atau (TPS) sebagaimana mestinya, kemudian mengurug diatas timbunan limbah batubara fly ash dan bottom ash tersebut dengan tanah merah adalah agar tidak ketahuan dan semata-mata untuk menghemat biaya,yang hanya memikirkan keuntungan bagi perusahaan milik terdakwa tanpa mengindahkan dampak/ akibatnya yang akan mencemari dan merusak lingkungan hidup.

d) Tindakan Andrian Sadikin Alias Ayen tersebut dianggap tindakan yang memimpin perusahaan memang sudah seharusnya dan sepantasnya untuk bertanggung jawab terhadap perbuatan yang dilakukan oleh badan usaha miliknya PT Assa Paper, sehingga unsur yg dipenuhi yakni Apabila tindak pidana lingkungan hidup dilakukan oleh, untuk, atau atas nama badan usaha, tuntutan pidana dan sanksi pidana dijatuhkan kepada orang yang memberi perintah untuk melakukan tindak pidana tersebut atau orang yang bertindak sebagai pemimpin kegiatan dalam tindak pidana tersebut".

\section{Analisa Pertanggungjawaban Pidana Pengurus Koperasi}

Menurut penulis kasus ini gagal membedakan korporasi dan pengurus korporasi sebagai subjek hukum untuk memberikan efek jera sekaligus pembelajaran bagi perusahaan yang melaukan tidakan serupaDalam uraian dakwaannya pun Jaksa tidak hanya menguraikan tindakan-tindakan Andrian Sadikin Alias Ayen secara pribadi tetapi tindakan yang dilakukan ole pengurus perusahaan dan staff PT Assa Papper sehingga apabila Jaksa Penuntut Umum ingin meminta pertanggungjawaban pidana kepada korporasi beserta pengurusnya, maka Jaksa Penuntut Umum seharusnya mencontoh Jaksa Penuntut Umum dalam kasus PT Newmont Minahasa Raya, di mana Jaksa menuntut 
korporasi sebagai Terdakwa I dan pengurus korporasi sebagai Terdakwa II.

Selain itu, Jaksa Penuntut Umum juga seharusnya menggunakan Pasal 46 ayat (1) UUPLH sebagai dasar apabila memang bertujuan untuk menjatuhkan pidana kepada pengurus korporasi. Apabila menggunakan pasal tersebut, Jaksa Penuntut Umum harus membuktikan bahwa Andrian Sadikin merupakan orang yang memberi perintah atau memimpin dilakukannya tindak pidana, yang juga termasuk membiarkan melakukan tindak pidana dilakukan oleh korporasi walaupun ia dapat mencegahnya. Berdasarkan uraian Jaksa, Andrian Sadikin mengetahui aktivitas pegawai-pegawainya dan bahkan beberapa tindakan disetujui oleh Andrian Sadikin sehingga memenuhi unsur memberi perintah atau memimpin. Di sini, Jaksa tidak menggunakan Pasal 46 ayat (1). Dalam tuntutannya pun Jaksa tidak secara jelas hanya menuntut Andrian Sadikinsebagai individu, karena terdapat keterangan bahwa Andrian Sadikindituntut sebagai wakil dari korporasi. Seharusnya Jaksa hanya menuntut Andrian Sadikinsebagai individu.

Selain itu menurut fakta yang terbukti di persidangan dan pertimbangan majelis hakim, menurut penulis memang PT Assa Paper dapat dibebankan pertanggungjawaban pidana, baik atas tindakan pegawainya berdasarkan teori corporate vicarious liability yakni teori pertanggungjawaban di mana seseorang bertanggung jawab atas perbuatan orang lain. Selain itu bila dikaitkan dengan korporasi maka berdasarkan teori tersebut tidak hanya terbatas kepada karyawan dalam posisi tertentumaka actus reus dan mens rea dari individu yang bertindak atas nama korprasi secara otomatis juga dilekatkan kepada korporasi.

Selain itu juga tindakan para pegawai dan para pengurus berdasarkan teori agregasi yakni teori yang menyatakan bahwa tidak mengharuskan adanya individu tertentu yang memenuhi semua unsur-unsur kejahatan untuk dapat membebankan pertanggungjawaban pidana kepada korporasi. Berdasarkan teori ini, korporasi bertanggung jawab apabila secara kolektif tindakan individu-individu di dalam korporasi memenuhi unsur tindak pidana. Pertanggungjawaban berasal dari penjumlahan pikiran atau kesalahan dari individu-individu yang mewakili korporasi. Namun, karena PT Assa Paper tidak pernah dijadikan terdakwa sebelumnya, maka korporasi tidak dibebankan pertanggungjawaban pidana.

\section{SIMPULAN}

1. Ketentuan di Indonesia mengenai apa yang dimaksud dengan tindak pidana korporasi serta kapan pengurusnya dapat dibebankan pertanggungjawaban pidana masi belum jelas. Beberapa ketentuan dalam undang-undang masih menggunakan teori individual vicarious liablity yang mana pengurus dapat dipidana tanpa adanya kesalahan. Ketentuan-ketentuan ini tidak membedakan antara pertanggungjawaban pidana korporasi dengan pertanggungjawaban pidana pengurus korporasi. Ketentuan dengan teori individual vicarious liability hanya berlaku pada tindak pidana lingkungan hidup tertentu yang secara jelas diatur dalam undang-undang.

2. Dalam analisa kasus tersebut majelis hakim masih menjadikan pengurus korporasi sebagai terdakwa tanpa mendakwa korporasinya. Hal ini dapat menjadikan kasus berulang terhadap perusahaan yang sama.

\section{SARAN}

UUPPLH pada dasarnya dibentuk dengan tujuan membuat jera korporasi dan juga pengurusnya yang melakukan kejahatan lingkungan dapat tercapai, sehingga pembuat undang-undang harus memperluas ruang lingkup tindakan korporasi sehingga tidak hanya terbatas pada teori tertentu atau teori identifikasi. Adapun korporasi sebenarnya juga dapat dibebankan pertanggungjawaban pidana berdasarkan teori vicarious corporate liability, aggregation theory, dan organizational models (yang terdiri dari corporate policy, corporate culture, dan 
reactive corporate fault). Selain memperluas cakupan pembuat undang-undang juga dapat menambahkan ketentuan siapa yang dapat dibebankan pertanggungjawaban pidana sehingga tidak terbatas pada jabatan tertentu seperti direktur atau manajer, tetapi dapat pula menjangkau individu manapun yang terlibat dalam manajemen di perusahaan dan berada dalam posisi yang dapat mempengaruhi dilakukannya tindak pidana oleh korporasi.

\section{DAFTAR PUSTAKA}

Andri Gunawan Wibisana dan Andreas Nathaniel Marbun. (2018). Corporate Criminal Liability in Indonesia Anti-Corruption Law: Does it Work Properly?. Sweden: Asian Journal of Law and Economics.

Andri Gunawan Wibisana. (2016). Kejahatan Lingkungan oleh Korporasi: Mencari Bentuk Pertanggungjawaban Korporasi dan Pemimpin/Pengurus Korporasi untuk Kejahatan Lingkungan di Indonesia. Jakarta: Jurnal Hukum \& Pembangunan.

Cristina de Maglie, (2005). Models of Corporate Criminal Liability in Comparative Law. Washington University Global Studies Law Review, Vol. 4.

Danusaputro, Munadjat. (1985). Hukum Lingkungan Buku I: Umum. Jakarta: Binacipta.

Edorita, Widia. (2007). Peranan Amdal Dalam Penegakan Hukum Lingkungan Di Indonesia Dan Perbandingannya dengan Beberapa Negara Asia Tenggara. Padang: Universitas Andalas.

Indonesia, Undang-Undang Perlindungan dan Pengelolaan Lingkungan Hidup, UU No. 32 Tahun 2009, LN No.140 Tahun 2009, TLN No.5059.

Peter Mahmud Marzuki. (2009). Penelitian Hukum. Jakarta: Kencana Prenada Media Group.

Protection of the Environment Operations Act 1997.
Putusan Pengadilan Negeri Purwokerto Nomor 55/Pid.B/LH/2016/PN.Pwk

Raynaldo Sembiring, et.al. (2014). Anotasi Undang-Undang No. 32 Tahun 2009 tentang Perlindungan dan Pengelolaan Lingkungan Hidup". Jakarta: Indonesian Center for Environmental Law.

Siahaan, N.H.T. (2004). Hukum Lingkungan dan Ekologi Pembangunan. Jakarta: Erlangga.

Silalahi, Daud. (2001). Hukum Lingkungan Dalam Sistem Penegakan Hukum Lingkungan Indonesia. Bandung: PT Alumni.

Soerjono Soekanto dan Sri Mamudji. (2009). Penelitian Hukum Normatif Suatu Tinjauan Singkat. Jakarta: Raja Grafindo Persada.

Soerjono Soekanto. (1986). Pengantar Penelitian Hukum, Cet.3. Jakarta: Penerbit Universitas Indonesia (UIPress).

Sutan Remy Sjahdeini, (2017). Ajaran Pemidanaan: Tindak Pidana Korporasi \& Seluk- Beluknya, Jakarta: Kencana. 